\title{
Traditional serrated adenoma of the sigmoid colon with osseous metaplasia: a case report
}

\author{
Nelson F Montalvo ${ }^{*}$, José N Beltrán and Ligia A Redrobán ${ }^{1}$
}

\begin{abstract}
Introduction: Osseous metaplasia in the gastrointestinal tract is a rare phenomenon.

Case presentation: We present the case of a 62-year-old Hispanic man with two colonic polypoid lesions, one of which, upon resection and histopathological examination, was found to be a traditional serrated adenoma with a focus of stromal osseous metaplasia.

Conclusions: Our patient's case is the third report of stromal osseous metaplasia in a traditional serrated adenoma of the sigmoid colon.
\end{abstract}

\section{Introduction}

Epithelial metaplasia is a common occurrence in the gastrointestinal tract (GIT), especially in the upper GIT (excluding the liver and pancreas). However, mesenchymal metaplasia, particularly osseous metaplasia (OM), is a rare and incidental finding in the GIT and is composed of histologically benign bone tissue [1-3]. Fewer than 100 cases have been described in the literature. Gruber, in 1913, was the first to describe a case of osseous metaplasia in a gastric adenocarcinoma [4].

In 1939, Dukes described four cases of OM in colonic adenocarcinomas; since then, it has been described in both benign and malignant GIT lesions. The rectal region is particularly affected (adenocarcinoma), although the spectrum of presentation includes Barrett's esophagus; tubular, tubulovillous and serrated adenomas; juvenile and hyperplastic polyps; and appendicular tumors (Table 1). A number of histopathological characteristics have been associated with $\mathrm{OM}$ development: mucin extravasation, chronic and active inflammation and/or ulceration, necrotic tissue, and stromal fibroblastic proliferation [5-9].

\section{Case presentation}

A 62-year-old Hispanic man with no prior history of gastrointestinal problems presented for a routine endoscopic examination. He had no family history of colorectal cancer or polyps. He had a polyp $30 \mathrm{~cm}$ from the anal margin that was removed through open polypectomy and rectoscopy.

Macroscopically, the specimen was a $5 \times 3.5 \times 2 \mathrm{~cm}$ sessile polyp with a reddish, villous surface and a $4.5 \times 2 \mathrm{~cm}$ implantation base. The tissue was fixed in $10 \%$ formol, embedded in paraffin, cut at $4 \mu \mathrm{m}$, and subsequently stained with hematoxylin and eosin.

Microscopically, at low power the specimen was a traditional serrated adenoma (TSA) of colonic mucosa (sigmoid) with exuberant, villiform growth pattern and complex serration. High power examination disclosed eosinophilic pencillate cells, numerous ectopic crypts and low-grade epithelial dysplasia. (Figures 1 and 2) The fibrovascular axes showed numerous lymphangiectasias. In one of the axes a single small focus of stromal osseous metaplasia consisting of normal-looking osseous trabeculae with peripheral retraction and hemorrhage was detected. No characteristic was identified (chronic or active inflammation, ulceration, hyalinization or mucin extravasation) that would suggest a traumatic or ischemic process (Figure 3).

\section{Discussion}

Mesenchymal metaplasia, particularly osseous metaplasia, is an unusual finding in GIT, composed of

\footnotetext{
* Correspondence: nmontalvof@gmail.com

${ }^{1}$ Servicio de Patología, Hospital Metropolitano, Av. Mariana de Jesús s/n y Nicolás Arteta, Quito, Ecuador

Full list of author information is available at the end of the article
} 
Table 1 Osseous metaplasia in gastrointestinal tract lesions

\begin{tabular}{|c|c|c|}
\hline Location & Histopathological diagnoses & References \\
\hline Esophagus & Barrett's esophagus & {$[1,4]$} \\
\hline Stomach & Hyperplastic polyp, carcinoid tumor, adenocarcinoma & {$[2-5]$} \\
\hline Small intestine & Peutz-Jeghers syndrome, adenocarcinoma (peri-ampullary region) & {$[3,4,6,10]$} \\
\hline Cecal appendix & Mucocele, mucinous cystadenocarcinoma, adenocarcinoma & {$[3-5]$} \\
\hline Ascending colon & Metastatic signet-ring cell, adenocarcinoma & {$[4,5,7]$} \\
\hline Transverse colon & Hyperplastic polyp, tubular adenoma, adenocarcinoma & {$[3,4,8,10-12]$} \\
\hline Descending colon & Tubular adenoma, tubulovillous adenoma & {$[3,4,8,10,13]$} \\
\hline Unspecified colon & Adenocarcinoma & {$[3,4,7,9,11,14]$} \\
\hline Rectum & $\begin{array}{l}\text { Proctocolitis, solitary rectal ulcer syndrome, } \\
\text { adenoacanthoma, juvenile polyp, traditional } \\
\text { serrated adenoma*, tubular adenoma, tubulovillous } \\
\text { adenoma, adenocarcinoma with squamous } \\
\text { metaplasia, adenocarcinoma arising in a traditional } \\
\text { serrated adenoma }\end{array}$ & {$[1-5,8,9,11,12,14-16]$} \\
\hline
\end{tabular}

*Third case reported in the literature.

histologically benign bone tissue. This is an unexpected variation of the usual histological features encountered in colorectal TSA. In 1939, Dukes described four cases of $\mathrm{OM}$ in colonic adenocarcinoma; since then, it has been described in both benign and malignant GIT lesions, but the rectal region is particularly affected $[1,3,8]$.

Despite the absence of a conclusive explanation of the induction mechanism of ossification, the hypothesis proposed by Rhone and Horowitz in 1976 postulated the metaplasia of a pluripotent cell into an osteoblast under the influence of factors generated by epithelial cells. One possible mechanism includes the production of bone morphogenetic proteins (BMP)- 5 and BMP- 6 by epithelial cells and BMP-2 and BMP-4 by adjacent fibroblasts [9-11,13,15,16].

An extensive review of the literature reveals that $\mathrm{OM}$ is mostly described in association with colorectal carcinomas and adenomas (both tubular and villous); however, no risk association has been determined for sex, age or polyp size

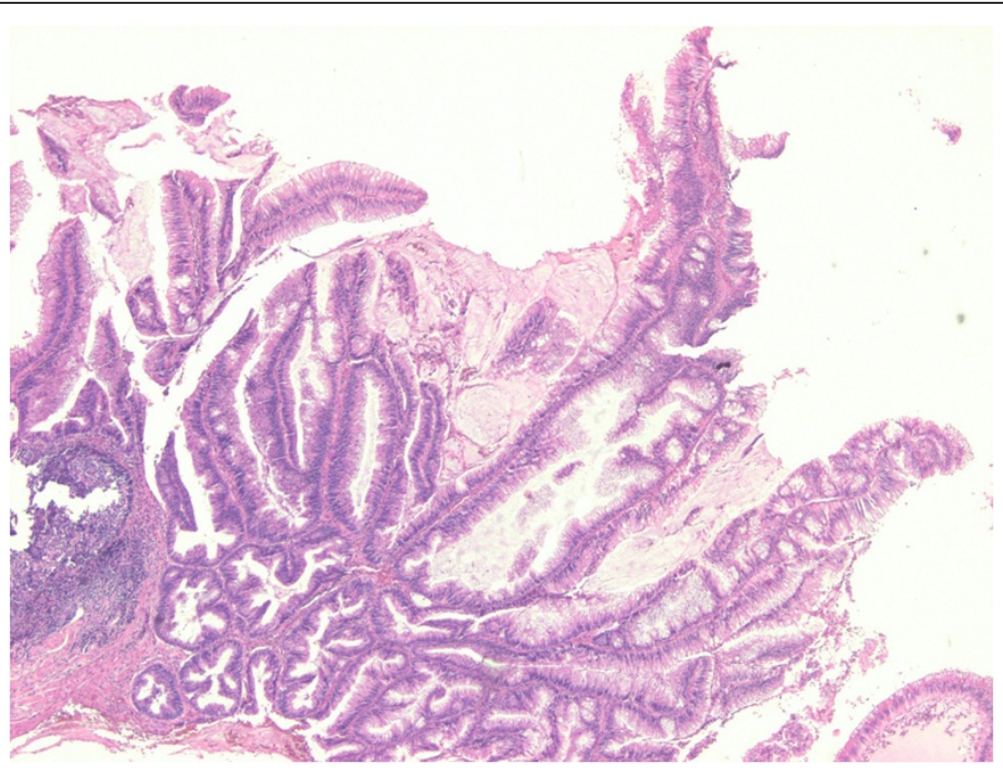

Figure 1 Traditional serrated adenoma of colonic mucosa (sigmoid) (hematoxylin and eosin staining, $2 \times$ ). 


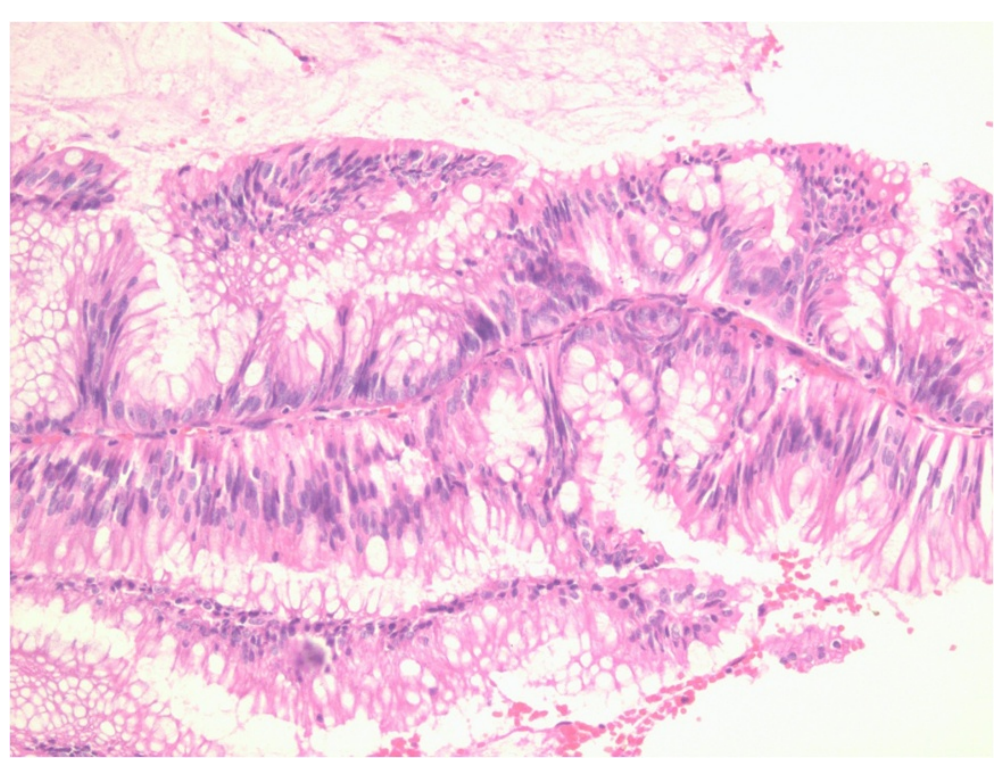

Figure 2 Cells lining the villi are eosinophilic with small ectopic crypts (hematoxylin and eosin staining, 10x).

$[5,8,9,11]$. This is the third reported case of OM in a traditional serrated adenoma. As in the first, there was no malignant transformation, in contrast to the second case reported, in which an adenocarcinoma had developed $[12,14]$. The site in all three cases was the left colon.

\section{Conclusions}

According to our bibliographic review, our patient's case is only the third report of osseous metaplasia in the stroma of a traditional serrated adenoma located in the sigmoid colon. No characteristic has been identified that

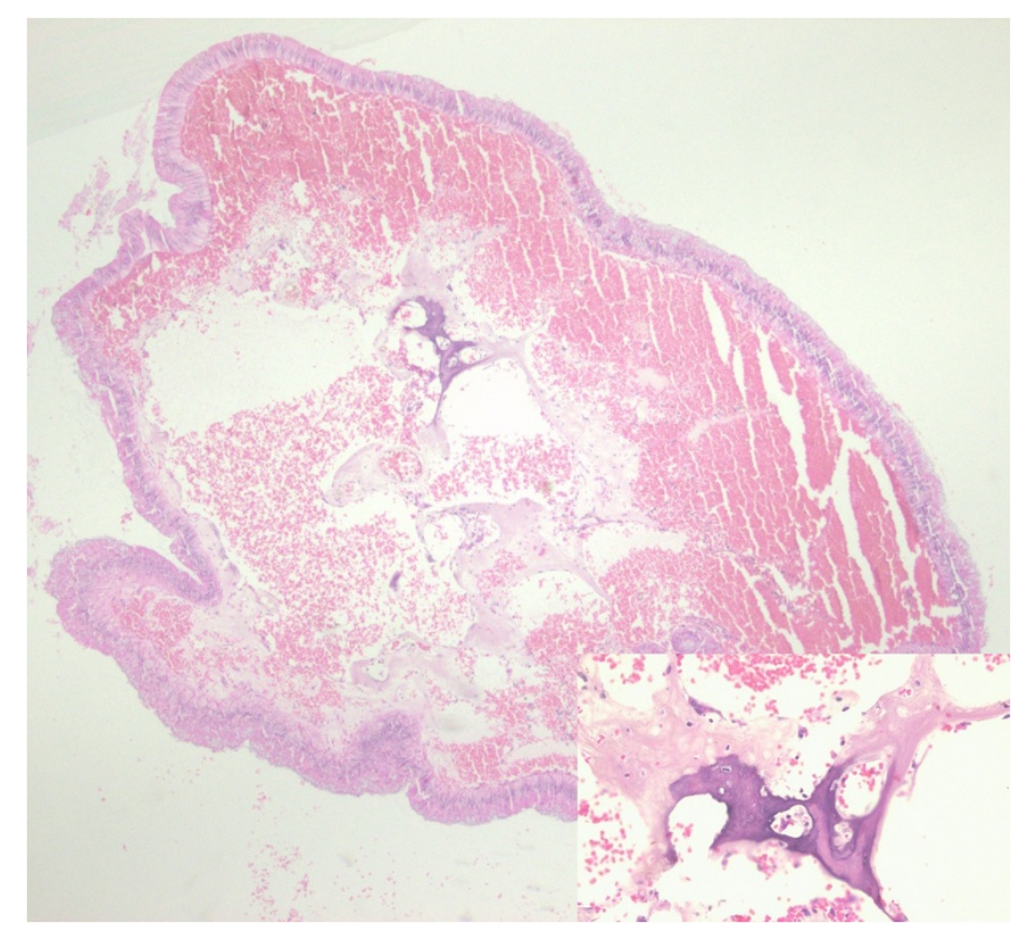

Figure 3 Fibrovascular axis. Inset: focus of osseous metaplasia (hematoxylin and eosin staining, 40x). 
would suggest a traumatic or ischemic process, nor any foci of calcification, either proximal or distal.

\section{Consent}

Written informed consent was obtained from the patient for publication of this case report and accompanying images. A copy of the written consent is available for review by the Editor-in-Chief of this journal.

\section{Competing interests}

The authors declare that they have no competing interests.

\section{Acknowledgements}

The authors wish to thank Dr Francisco Estrella for his valuable technical support.

\section{Author details}

${ }^{1}$ Servicio de Patología, Hospital Metropolitano, Av. Mariana de Jesús s/n y Nicolás Arteta, Quito, Ecuador. ${ }^{2}$ Servicio de Patología, Hospital del IESS, Ibarra, Ecuador.

\section{Authors' contributions}

NM performed the histological examination and diagnosis of the colonic polyp. JB and LR conducted a thorough literature review on osseous metaplasia in the gastrointestinal tract and were the major contributors in writing the manuscript. All authors read and approved the final manuscript.

Received: 12 October 2011 Accepted: 23 May 2012

Published: 23 May 2012

\section{References}

1. Randall JC, Morris DC, Tomita T, Anderson HC: Heterotopic ossification: a case report and immunohistochemical observations. Hum Pathol 1989, 20:86-88.

2. Drut R, Cueto E: Metaplasia ósea en pólipos juveniles. Presentación de dos casos. Patología 1992, 30:33-36.

3. Narita T, Ohnuma H, Yokoyama S: Peutz-Jeghers syndrome with osseous metaplasia of the intestinal polyps. Pathol Int 1995, 45:388-392.

4. Haque S, Eisen RN, West AB: Heterotopic bone formation in the gastrointestinal tract. Arch Pathol Lab Med 1996, 120:666-670.

5. Kypson AP, Morphew E, Jones R, Gottfried MR, Seigler HF: Heterotopic ossification in rectal cancer: rare finding with novel proposed mechanism. J Surg Oncol 2003, 82:132-136.

6. Carmen Z, Arnoldo V, Margarita S, et al: Metaplasia ósea del estroma en un adenocarcinoma papilar de la región periampular [Stromal osseous metaplasia in a papillary adenocarcinoma of the periampullary region] Patología 2002, 40:43-45.

7. Alper M, Akyürek N, Patiroğlu TE, Yüksel O, Belenli O: Heterotopic bone formation in two cases of colon carcinoma. Scand I Gastroenterol 2000 5:556-558.

8. Al-Daraji W, Abdellaoui A, Salman W: Osseous metaplasia in a tubular adenoma of the colon. J Clinic Pathol 2000, 58:220-221.

9. Imai N, Iwai A, Hatakeyama S, Matsuzaki K, Kitagawa Y, Kato S, Hokari R, Kawaguchi A, Nagao S, Miyahara T, Itoh K, Miura S: Expression of bone morphogenetic proteins in colon carcinoma with heterotopic ossification. Pathol Int 2001, 51:643-648.

10. Cavazza A: Osseous metaplasia in colonic adenomas (letter). J Clin Pathol 2005, 58:220-221.

11. Nassif T, Zanditenas D, Lazure T, Paterne D, Kuhl E, Buffet C: Osseous metaplasia in a colonic adenocarcinoma [in French]. Gastroenterol Clin Biol 2003, 27:1035-1037.

12. Wilsher $\mathrm{M}$, Mendelsohn G: Osseous metaplasia in a traditional serrated adenoma of the rectosigmoid colon. Pathology 2010, 42:302-304.

13. White V, Shaw AG, Tierney GM, Lund JN, Semeraro D: Osseous metaplasia in an ulcerating tubular adenoma of the colon: a case report. J Med Case Reports 2008, 2:130-132.

14. Wilsher MJ: Adenocarcinoma arising in a traditional serrated adenoma of the rectosigmoid colon with osseous metaplasia. Pathol Int 2011, 61:239-242.
15. Matsumoto T, Masuda T, Inomata M, Kitano S, Kashima K, Shibata K, Arinaga S: Heterotopic ossification of rectal adenocarcinoma: report of a case. Surg Today 2004, 34:167-169.

16. Billingham K, Radojkovic M: Osseous metaplasia of the colon in a diversion proctocolitis. Int J Surg Pathol 2009, 17:81-83.

doi:10.1186/1752-1947-6-133

Cite this article as: Montalvo et al.: Traditional serrated adenoma of the sigmoid colon with osseous metaplasia: a case report. Journal of Medical Case Reports 2012 6:133.

\section{Submit your next manuscript to BioMed Central and take full advantage of:}

- Convenient online submission

- Thorough peer review

- No space constraints or color figure charges

- Immediate publication on acceptance

- Inclusion in PubMed, CAS, Scopus and Google Scholar

- Research which is freely available for redistribution 